\title{
PERBEDAAN PENGGUNAAN PENDEKATAN KOOPERATIF TIPE NUMBERED HEAD TOGETHER DAN THINK PAIR SHARE TERHADAP KEMAMPUAN MENULIS TEKS CERPEN SISWA KELAS VII SMP NEGERI 12 PADANG
}

\author{
Rahayu Fitri \\ STKIP PGRI Sumatera Barat \\ rahayu@ stkip-pgri-sumbar.ac.id
}

Naskah diterima: 2 September 2017; direvisi: 29 Oktober 2017; disetujui: 20 November 2017

\begin{abstract}
This research were aims to describe the things as follows. First, the ability to write a short story text students of class VII SMP Negeri 12 Padang taught by using cooperative approach Numbered Head Together type. Second, the ability to write short story text students of class VII SMP Negeri 12 Padang taught by using cooperative approach Think Pair Share type. Third, the difference in ability to write short story text students of class VII SMP Negeri 12 Padang taught by cooperative approach Numbered Head Together and Think Pair Share type. This research was quantitative with descriptive method of quasi experimental research design. Sampling was done by using simple random sampling technique. In this research, class VII.3 was assigned as experiment class I which amounted to 32 students and VII.5 as experiment class II which amounted to 30 students. Data collected by using performance test writing short story text. The results of this study are as follows. First, the ability to write a short story text students of class VII SMP Negeri 12 Padang taught by using cooperative approach Numbered Head Together type was 89,58. Second, the ability to write short story text students of class VII SMP Negeri 12 Padang taught by using cooperative approach Think Pair Share type was 81,48. Third, there was a significant difference in ability to write short story text of students in class VII SMP Negeri 12 Padang taught by cooperative approach Numbered Head Together and Think Pair Share type.
\end{abstract}

Keywords: Numbered Head Together, Think Pair Share, short story text

\begin{abstract}
ABSTRAK
Penelitian ini bertujuan untuk mendeskripsikan hal-hal sebagai berikut. Pertama, kemampuan menulis teks cerpen siswa kelas VII SMP Negeri 12 Padang yang diajarkan dengan menggunakan pendekatan kooperatif tipe Numbered Head Together. Kedua, kemampuan menulis teks cerpen siswa kelas VII SMP Negeri 12 Padang yang diajarkan dengan menggunakan pendekatan kooperatif tipe Think Pair Share. Ketiga, perbedaan kemampuan menulis teks cerpen siswa kelas VII SMP Negeri 12 Padang yang diajarkan dengan pendekatan kooperatif tipe Numbered Head Together dan Think Pair Share. Jenis penelitian ini adalah kuantitatif dengan metode deskriptif rancangan quasi experimental research (eksperimen semu). Penarikan sampel dilakukan dengan menggunakan teknik simple random sampling. Pada penelitian ini, ditetapkan kelas VII.3 sebagai kelas eksperimen I yang berjumlah 32 orang dan VII.5 sebagai kelas eksperimen II yang berjumlah 30. Data dikumpulkan dengan menggunakan tes unjuk kerja menulis teks cerpen. Hasil penelitian ini ialah sebagai berikut. Pertama, kemampuan menulis teks cerpen siswa kelas VII SMP Negeri 12 Padang yang diajarkan dengan menggunakan
\end{abstract}


pendekatan kooperatif tipe Numbered Head Together ialah 89,58. Kedua, kemampuan menulis teks cerpen siswa kelas VII SMP Negeri 12 Padang yang diajarkan dengan menggunakan pendekatan kooperatif tipe Think Pair Share ialah 81,48. Ketiga, terdapat perbedaan yang signifikan kemampuan menulis teks cerpen siswa kelas VII SMP Negeri 12 Padang yang belajar dengan pendekatan kooperatif tipe Numbered Head Together dan Think Pair Share.

Kata kunci: Numbered Head Together, Think Pair Share, Teks Cerpen

\section{PENDAHULUAN}

Pembelajaran Bahasa Indonesia dalam kurikulum 2013 mengalami perubahan yang mendasar, yaitu berbasis teks yang bertujuan agar dapat membawa siswa sesuai dengan perkembangan mentalnya, dan menyelesaikan masalah kehidupan nyata dengan berpikir kritis. Pembelajaran berbasis teks dalam mata pelajaran Bahasa Indonesia lebih menekankan pada siswa untuk memahami berbagai jenis teks dan menuntut siswa untuk mahir menulis. Mahsun (2014:2) menyatakan bahwa teks merupakan satuan bahasa yang digunakan sebagai ungkapan suatu kegiatan sosial baik secara lisan maupun tulis dengan struktur berpikir yang lengkap.

Salah satu jenis teks yang harus mampu ditulis oleh siswa SMP kelas VII adalah teks cerpen. Hal tersebut terdapat di Standar Isi Kurikulum 2013 untuk tingkat SMP/MTs kelas VII pada Kompetensi Inti (KI) 4, yaitu mencoba, mengelolah, dan menyaji dalam ranah konkret (menggunakan, mengurai, merangkai, memodifikasi, dan membuat) dan ranah abstrak (menulis, membaca, menghitung, menggambar, dan mengarang) sesuai dengan yang dipelajari di sekolah dan sumber lain yang sama dalam sudut pandang atau teori dan Kompetensi Dasar (KD) 4.2, yaitu menyusun teks hasil observasi, tanggapan deskriptif, eksposisi, eksplanasi, dan cerita pendek sesuai dengan karakteristik teks yang akan dibuat baik secara lisan maupun tulisan. Salah satu tuntutan KI dan KD tersebut ialah agar siswa mampu menulis teks cerpen. Menurut Kokasih (2016:111), "teks cerita pendek (cerpen), yakni cerita yang menurut wujudnya berbentuk pendek. Ukuran panjang pendeknya suatu cerita memang relatif. Namun, pada umumnya cerita pendek merupakan cerita yang habis dibaca sekitar sepuluh menit atau setengah jam. Jumlah katanya sekitar 500-5.000 kata. Karena itu, cerita pendek sering diungkapkan dengan cerita yang dapat dibaca dalam sekali duduk.

Teks cerpen memiliki tiga struktur, yaitu (1) orientasi, (2) komplikasi, dan (3) resolusi. Orientasi merupakan bagian awal yang berisi pengenalan tokoh, latar tempat dan waktu, kemudian awalan masuk ke tahapan berikutnya. Komplikasi merupakan bagian yang berisi tokoh utama berhadapan dengan masalah (konflik). Resolusi merupakan kelanjutan dari komplikasi, yaitu pemecahan masalah yang ada pada teks cerpen (Kemendikbud, 2013:152).

Namun, berdasarkan hasil pengamatan yang dilakukan pada siswa kelas VII SMP Negeri 12 Padang, menunjukkan bahwa kemampuan menulis teks cerpen siswa masih rendah. Hal tersebut disebabkan oleh pemilihan teknik pembelajaran. Pemilihan teknik pembelajaran harus disesuaikan dengan karakteristik siswa dan materi ajarnya. Hal ini sesuai dengan pendapat Rusman (2012:133), "pemilihan model pembelajaran harus mempertimbangkan tujuan yang hendak dicapai, bahan atau materi pelajaran, dan sudut pandang peserta didik". Penggunaan pendekatan pembelajaran yang tepat juga berdampak pada hasil yang diperoleh siswa nantinya. Agar hasil belajar dalam menulis teks cerpen menjadi lebih baik, dalam 
penelitian ini digunakan pendekatan kooperatif.

Pada pembelajaran kooperatif, siswa dikondisikan secara berkelompok sehingga siswa akan memperoleh kesempatan yang lebih untuk bertanya baik kepada sesama anggota kelompoknya maupun kepada guru. Pembelajaran berkelompok akan dapat memacu siswa untuk bekerja sama, saling membantu satu sama lain dalam mengintegrasikan pengetahuanpengetahuan baru dengan pengetahuan yang telah dimilikinya dengan anggota kelompok masing-masing (Nurhadi \& Senduk, dalam Naf'anudiniyah dkk, 2013:172).

Dalam penelitian ini, pendekatan kooperatif yang digunakan ialah tipe Numbered Head Together dan Think Pair Share. Numbered Head Together adalah suatu metode pengelompokan siswa. Setiap siswa dalam kelompok diberi nomor lalu guru memberikan tugas untuk dikerjakan masing-masing kelompok dan kemudian guru memanggil salah satu nomor untuk melaporkan hasil kerja sama mereka (Lie, 2005:60). Dalam metode ini, siswa diharapkan dapat bekerja sama dengan anggota kelompok lainnya, serta diharapkan semua siswa memiliki kesiapan untuk menerangkan hasil diskusi dan menjawab pertanyaan-pertanyaan dari guru karena semua siswa mempunyai kesempatan yang sama untuk ditunjuk. Semua siswa akan memahami materi serta mempersiapkan diri agar bisa menerangkan hasil diskusi dan menjawab pertanyaanpertanyaan dari guru. Dengan metode ini, diharapkan dapat menumbuhkan jiwa tanggung jawab dalam diri setiap siswa khususnya sebagai anggota kelompok.

Menurut Trianto (2012:82), Numbered Head Together atau penomoran berpikir bersama merupakan jenis pembelajaran kooperatif yang dirancang untuk mempengaruhi pola interaksi siswa. Numbered Head Together dapat digunakan untuk melibatkan lebih banyak siswa dalam menelaah materi yang tercangkup dalam suatu pelajaran dan mengecek pemahaman mereka terhadap isi pelajaran tersebut. Hal tersebut sesuai dengan hasil penelitian Huda (2015:149) bahwa "pembelajaran dengan model pembelajaran kooperatif tipe Numbered Head Together memiliki dampak positif dalam meningkatkan hasil belajar siswa IPA yang ditandai dengan peningkatan ketuntasan belajar siswa dalam setiap siklus, yaitu siklus I (64\%) mengalami kenaikan hingga tuntas klasiklal padaSiklus II (94.11\%)".

Selain Numbered Head Together, dalam penelitian ini, juga diterapkan Think Pair Share. Menurut Trianto (2012:81), Think Pair Share atau berpikir berpasangan berbagi merupakan jenis pembelajaran kooperatif yang dirancang untuk mempengaruhi pola interaksi siswa. Think Pair Share ini berkembang dari penelitian belajar kooperatif dan waktu tunggu. Think pair Share memiliki prosedur yang dinyatakan secara eksplisit untuk memberi siswa waktu lebih banyak untuk berpikir, menjawab, dan saling membantu satu sama lain (Ibrahim dkk, 2005:26). Model pembelajaran kooperatif tipe Think pair Share merupakan salah satu model pembelajaran kooperatif yang terdiri dari 2 orang/berpasangan. Setiap anggota kelompok saling bekerja sama untuk mendiskusikan tiap masalah yang diberikan guru. Setelah itu, mempresentasikan hasil diskusi (Lie, 2005:45).

Hal tersebut sesuai dengan hasil penelitian Sianturi dan Daulay (2015:11) bahwa "perolehan nilai sesudah menggunakan model pembelajaran kooperatif tipe Think Pair Share lebih unggul daripada perolehan nilai yang tidak memakai model pembelajaran. Pendekatan pembelajaran Kooperatif tipe Think Pair Share sangat efektif untuk menarik minat siswa dan membantu siswa mendapat informasi dalam proses pembelajaran". Melalui kedua tipe model pembelajaran kooperatif di atas, peserta didik didorong untuk mengkonstruksi pengetahuan sendiri atas dasar interaksi fisik dan juga melalui interaksi sosial peserta didik bersama peserta didik lainnya dan antara peserta didik 
bersama sumber belajar. Pendekatan kooperatif baik tipe Numbered Head Together maupun Think Pair Share, menekankan diperolehnya pengalaman belajar dan refleksinya yang merupakan kunci dari pengalaman belajar bermakna (Hartati dan Sudarisman, 2011:272). Berdasarkan permasalahan-permasalahan tersebut, penting dilakukan penelitian guna mendeskripsikan perbedaan kemampuan menulis teks cerpen siswa kela VII SMP Negeri 12 Padang yang diajarkan dengan pendekatan kooperatif tipe Numbered Head Together dan Think Pair Share.

\section{METODE PENELITIAN}

Jenis penelitian ini adalah penelitian kuantitaif dengan metode deskriptif dan rancangan penelitian berbentuk eksperimental semu (quasi experimental research). Populasi penelitian ini adalah seluruh siswa kelas VII SMP Negeri 12 Padang pada tahun ajaran 2016/2017. Jumlah populasi dalam penelitian ini adalah 188 orang yang tersebar dalam 6 kelas. Penarikan sampel dilakukan dengan teknik simple random sampling atau teknik penarikan sampel secara acak sederhana. Pada penelitian ini, siswa dikelompokkan menjadi dua kelompok, yaitu kelas eksperimen I dan kelas eksperimen II. Kelas eksperimen I diajarkan dengan menggunakan pendekatan kooperatif tipe Numbered Head Together dan kelas eksperimen II dengan menggunakan pendekatan kooperatif tipe Think Pair Share. Selanjutnya, pada kedua kelas tersebut, diberikan materi dan tes pembelajaran yang sama. Setelah dilakukan uji normalitas dan homogenitas pada populasi penelitian, terpilih kelas VII.3 sebagai kelas eksperimen I yang berjumlah 32 orang dan VII.5 sebagai kelas eksperimen II yang berjumlah 30 orang karena kedua kelas tersebut merupakan kelas yang normal dan homogen. Selain itu, kedua kelas juga memiliki nilai ratarata yang relatif sama.

Instrumen pengumpulan data yang digunakan adalah tes unjuk kerja menulis teks cerpen. Adapun indikator yang ditetapkan untuk penilaian menulis teks cerpen ialah struktur teks cerpen yang terdiri dari orientasi, komplikasi, dan resolusi. Data penelitian dianalis dengan menggunakan teknik statistik. Teknik tersebut digunakan untuk melihat perbedaan variabel bebas (X) dengan variabel terikat (Y). Dari analisis data, diperoleh kesimpulan-kesimpulan yang dapat menerima dan menolak hipotesis yang telah dirumuskan. Langkah-langkah yang dilakukan sebagai berikut. Pertama, pendeskripsian data. Kedua, pengujian persyaratan analisis meliputi: uji normalitas dengan uji liliefors, dan uji homogenitas dengan uji F. Ketiga, pengujian hipotesis dilakukan dengan menggunakan rumus uji-t.

\section{HASIL DAN PEMBAHASAN}

Hasil penelitian terdiri dari tiga bagian, yaitu hasil penelitian berupa kemampuan menulis teks cerpen siswa kelas VII SMP Negeri 12 Padang di kelas eksperimen I, hasil penelitian berupa kemampuan menulis teks cerpen siswa kelas VII SMP Negeri 12 Padang di kelas eksperimen II, dan hasil pengujian hipotesis. Hasil tersebut ialah sebagai berikut.

\section{Kemampuan Menulis Teks Cerpen Siswa di Kelas Eksperimen I}

Berdasarkan hasil analisis data, diperoleh nilai kemampuan menulis teks cerpen siswa di kelas eksperimen I yang tertinggi ialah 100 dan terendah ialah 66,67 . Nilai tersebut dapat dikelompokkan menjadi 4 kelompok, yaitu sebagai berikut. Pertama, nilai 66,67 diperoleh oleh 3 orang siswa (9,38\%). Kedua, nilai 77,78 diperoleh oleh 4 orang siswa (12,5\%). Ketiga, nilai 88,89 diperoleh oleh 13 orang siswa (40,63\%). Keempat, nilai 100 diperoleh oleh 12 orang siswa $(37,5 \%)$. Nilai rata-rata kemampuan menulis teks cerpen siswa di kelas eksperimen I ialah 89,58 dengan standar deviasi sebesar 10,54 . 
Adapun indikator yang digunakan untuk menilai kemampuan menulis teks cerpen siswa ialah struktur teks cerpen yang terdiri dari orientasi, komplikasi, dan resolusi. Nilai kemampuan menulis teks cerpen siswa jika dilihat dari masingmasing indikator ialah sebagai berikut. Pertama, untuk indikator 1, yaitu orientasi, nilai tertinggi yaitu 100 diperoleh 21 orang siswa $(65,63 \%)$; nilai 66,67 diperoleh oleh 10 orang siswa $(31,25 \%)$; dan nilai terendah yaitu 33,33 diperoleh oleh 1 orang siswa $(3,13 \%)$. Nilai rata-rata yang diperoleh oleh siswa untuk indikator 1 ialah 87,5 dengan standar deviasi sebesar 18,45. Kedua, untuk indikator 2. yaitu komplikasi, nilai 100 diperoleh oleh 20 orang siswa $(62,5 \%)$; dan nilai 66,67 diperoleh oleh 12 orang siswa $(37,5 \%)$. Nilai rata-rata yang diperoleh oleh siswa untuk indikator 2 ialah 87,5 dengan standar deviasi sebesar 16,4. Ketiga, untuk indikator 3, yaitu resolusi, nilai 100 diperoleh oleh 29 orang siswa $(90,63)$; dan nilai 33,33 diperoleh oleh 3 orang siswa $(9,38 \%)$. Nilai rata-rata yang diperoleh oleh siswa untuk indikator 3 ialah 93,75 dengan standar deviasi sebesar 19,74.

\section{Kemampuan Menulis Teks Cerpen Siswa di Kelas Eksperimen II}

Berdasarkan hasil analisis data, diperoleh nilai kemampuan menulis teks cerpen siswa di kelas eksperimen II yang tertinggi ialah 100 dan terendah ialah 55,56. Nilai tersebut dapat dikelompokkan menjadi 5 kelompok, yaitu sebagai berikut. Pertama, nilai 55,56 diperoleh oleh 3 orang siswa (10\%). Kedua, nilai 66,67 diperoleh oleh 5 orang siswa $(16,67 \%)$. Ketiga, nilai 77,78 diperoleh oleh 8 orang siswa (26,67\%). Keempat, nilai 88,89 diperoleh oleh 7 orang siswa $(23,33 \%)$. Kelima, nilai 100 diperoleh oleh 7 orang siswa (23,33\%). Nilai rata-rata kemampuan menulis teks cerpen siswa di kelas eksperimen II ialah 81,48 dengan standar deviasi sebesar 14,39.

Adapun indikator yang digunakan untuk menilai kemampuan menulis teks cerpen siswa ialah struktur teks cerpen yang terdiri dari orientasi, komplikasi, dan resolusi. Nilai kemampuan menulis teks cerpen siswa jika dilihat dari masingmasing indikator ialah sebagai berikut. Pertama, untuk indikator 1, yaitu orientasi, nilai tertinggi yaitu 100 diperoleh 12 orang siswa (40\%); nilai 66,67 diperoleh oleh 17 orang siswa $(56,67 \%)$; dan nilai terendah yaitu 33,33 diperoleh oleh 1 orang siswa $(3,33 \%)$. Nilai rata-rata yang diperoleh oleh siswa untuk indikator 1 ialah 78,89 dengan standar deviasi sebesar 18,54. Kedua, untuk indikator 2. yaitu komplikasi, nilai 100 diperoleh oleh 11 orang siswa (36,67\%); nilai 66,67 diperoleh oleh 15 orang siswa (50\%); dan nilai 33,33 diperoleh oleh 4 orang siswa $(13,33 \%)$. Nilai rata-rata yang diperoleh oleh siswa untuk indikator 2 ialah 74,44 dengan standar deviasi sebesar 22,63. Ketiga, untuk indikator 3, yaitu resolusi, nilai 100 diperoleh oleh 26 orang siswa $(86,67)$; nilai 66,67 diperoleh oleh 1 orang siswa (3,33\%); dan nilai 33,33 diperoleh oleh 3 orang siswa $(10 \%)$. Nilai rata-rata yang diperoleh oleh siswa untuk indikator 3 ialah 92,22 dengan standar deviasi sebesar 20,87 .

\section{Pengujian Hipotesis}

Sebelum dilakukan pengujian hipotesis, terlebih dahulu dilakukan pengujian persyaratan analisis data, yang meliputi uji normalitas dan homogenitas. Uji normalitas bertujuan untuk melihat hasil belajar sampel penelitian berdistribusi normal atau tidak. Rumus yang digunakan untuk mengetahui normalitas data adalah uji liliefors. Berdasarkan hasil uji normalitas, diperoleh hasil sebagai berikut. Pada kelas eksperimen I, nilai $\mathrm{L}_{0}=0,143$ dan $\mathrm{L}_{\mathrm{t}}=0,157$ pada $\mathrm{n}=32$ dan alpha $(\alpha)$ 0,05 . Pada kelas eksperimen II, diperoleh nilai $\mathrm{L}_{0}=0,136$ dan $\mathrm{L}_{\mathrm{t}}=0,161$ pada $\mathrm{n}=30$ dan alpha $(\alpha) 0,05$. Dengan demikian, data kemampuan menulis teks cerpen siswa di kelas eksperimen I dan kelas eksperimen II berdistribusi normal karena $\mathrm{L}_{0}<\mathrm{L}_{\mathrm{t}}$. 
Uji homogenitas dilakukan untuk mengetahui hasil tes menulis teks cerpen mempunyai varians yang homogen atau tidak. Uji homogenitas dalam penelitian ini menggunakan uji F. Berdasarkan hasil pengujian homogenitas di kelas eksperimen I dan kelas eksperimen II diperoleh nilai $F_{\text {hitung }}=1,84$ dan $F_{\text {tabel }}=1,86$ pada alpha $(\alpha) 0,05$ dan $\mathrm{n}_{1}=31-1=31$ dan $\mathrm{n}_{2}=30-1=29$. Dengan demikian, diperoleh data kemampuan menulis proposal penelitian mahasiswa di kelas eksperimen I dan kelas eksperimen II memiliki varians yang homogen karena $\mathrm{F}_{\mathrm{h}}<\mathrm{F}_{\mathrm{t}}$.

Untuk menguji signifikansi perbedaan kemampuan menulis teks cerpen siswa kelas VII SMP Negeri 12 Padang yang belajar dengan pendekatan kooperatif tipe Numbered Head Together dengan Think Pair Share dilakukan dengan uji-t dan membandingkan nilai thitung dengan $t_{\text {tabel }}$. Berdasarkan uji signifikansi dengan menggunakan uji-t, diperoleh nilai $t_{\text {hitung }}=2,61$ dan $t_{\text {tabel }}=1,697$ pada $\alpha=0,05$ dan $\mathrm{dk}=\mathrm{n}_{1}+\mathrm{n}_{2}-2=32+30-2=60$. Oleh karena itu, dapat disimpulkan bahwa $t_{\text {hitung }}>t_{\text {tabel }}=2,61>1,697$. Dengan demikian, $\mathrm{H}_{1}$ diterima dan $\mathrm{H}_{0}$ ditolak. Jadi, terdapat perbedaan yang signifikan kemampuan menulis teks cerpen siswa kelas VII SMP Negeri 12 Padang yang belajar dengan pendekatan kooperatif tipe Numbered Head Together dengan Think Pair Share.

Berdasarkan hasil penelitian yang dilakukan, diperoleh hasil bahwa kemampuan menulis teks cerpen dengan menggunakan pendekatan kooperatif tipe Numbered Head Together lebih baik baik daripada dengan menggunakan pendekatan kooperatif tipe Think Pair Share. Dengan menerapkan Numbered Head Together, siswa dibagi ke dalam kelompok dan kepada setiap anggota kelompok diberi nomor. Setelah itu, guru mengajukan sebuah pertanyaan kepada siswa. Dalam hal ini, guru memberikan pertanyaan yang terkait dengan materi teks cerpen. Kemudian, siswa menyatukan pendapatnya terhadap jawaban pertanyaan itu dan meyakinkan tiap anggota dalam timnya mengetahui jawaban tersebut. Sebelum guru menunjuk satu nomor, siswa dalam kelompok berdiskusi menyatukan pendapatnya. Guru memanggil satu nomor tertentu, kemudian siswa yang nomornya sesuai yang dipanggil mencoba menjawab pertanyaan untuk seluruh kelas.

Dalam hal ini, tampak tanggung jawab dari setiap siswa yang telah diberi nomor untuk mampu menguasai masing-masing materi. Siswa berdiskusi dalam kelompok setiap anggota yang lebih paham terhadap materi pelajaran atau pertanyaan yang diberikan oleh guru dapat membantu oleh siswa yang kurang paham sehingga setiap anggota kelompok dapat memahami dan menguasai materi pelajaran. Setiap anggota kelompok lebih banyak mendapatkan ideide dari teman satu kelompoknya. Setiap anggota kelompok lebih aktif dalam berinteraksi dengan teman sekelompoknya dan setiap anggota kelompok memiliki peran dan tanggung jawab yang sama dalam kelompoknya. Anggota dalam kelompok menjadi lebih serius dalam berdiskusi karena takut nomornya akan dipanggil oleh guru dan merasa malu jika tidak dapat menjawab pertanyan guru. Dengan demikian, antar anggota kelompok saling membantu agar perwakilan kelompok mereka dapat tampil dengan baik di depan kelas. Pada saat guru memanggil salah satu nomor untuk menjawab pertanyaan, mereka dapat menjelaskan dengan baik. Hal ini menunjukkan adanya keberhasilan dalam kelompok. Hal ini sesuai dengan pendapat Trianto (2012:82), "model pembelajaran NHT memiliki keunggulan yaitu rasa harga diri siswa lebih tinggi, pemahaman siswa akan lebih mendalam, hasil belajar lebih tinggi, penerimaan terhadap individu jadi lebih besar. Pembelajaran NHT mengutamakan kerja kelompok dari pada individual sehingga siswa bekerja dalam suasana kerja sama dan mempunyai kesempatan untuk menyalurkan informasi".

Dalam Think Pair Share, pembelajaran dimulai dengan guru mengajukan suatu 
pertanyaan atau masalah yang dikaitkan dengan pelajaran, dan meminta siswa menggunakan waktu beberapa menit untuk berpikir sendiri jawaban atau masalah. Selanjutnya, guru meminta siswa untuk berpasangan dan mendiskusikan hal yang mereka peroleh. Pada tahap akhir, guru meminta pasangan-pasangan untuk berbagi dengan keseluruhan kelas yang telah mereka bicarakan. Hal ini efektif untuk berkeliling ruangan dari pasangan ke pasangan dan melanjutkan sampai sekitar sebagian pasangan mendapatkan kesempatan untuk melaporkan. Pada kelas yang diajar dengan Think Pair Share, siswa yang telah memiliki pemikiran sendiri, harus berdiskusi dengan pasangannya. Kemudian, hasil pemikiran mereka harus dilaporkan kepada seluruh kelas. Dalam hal ini, siswa telah memiliki pemikiran dan pemecahan masalah sendiri terlebih dahulu sehingga lebih sulit menyatukan pemikirannya dengan pasangannya. Hal tersebut tidak terjadi pada saat melaksanakan Numbered Head Together yang dimulai dari pembentukan kelompok sehingga siswa belum memiliki pikiran masing-masing. Hal ini membuat proses diskusi lebih efektif.

Hal ini sesuai dengan hasil penelitian Arianto dan Rakhmawati (2013:319) bahwa "hasil belajar kelas eksperimen yang menggunakan model pembelajaran kooperatif tipe Numbered Heads Together (NHT) lebih baik dari pada hasil belajar siswa kelas kontrol yang menggunakan model pembelajaran kooperatif tipe Think Pair Shair (TPS)". Pada pendekatan kooperatif tipe Numbered Head Together dan Think Pair Share siswa dilatih untuk aktif berpikir, berdiskusi dan aktif dalam mengungkapkan ide yang mereka miliki dan guru hanya membimbing dan mengontrol jalannya proses belajar agar berjalan lancar".

\section{SIMPULAN}

Berdasarkan hasil penelitian, simpulan penelitian ini ialah sebagai berikut. Pertama, kemampuan menulis teks cerpen siswa kelas VII SMP Negeri 12 Padang dengan menggunakan pendekatan kooperatif tipe Numbered Head Together ialah 89,58. Kedua, kemampuan menulis teks cerpen siswa kelas VII SMP Negeri 12 Padang dengan menggunakan pendekatan kooperatif tipe Think Pair Share ialah 81,48. Ketiga, terdapat perbedaan yang signifikan kemampuan menulis teks cerpen siswa kelas VII SMP Negeri 12 Padang yang belajar dengan pendekatan kooperatif tipe Numbered Head Together dengan Think Pair Share. Dengan demikian, kemampuan menulis teks cerpen dengan menggunakan pendekatan kooperatif tipe Numbered Head Together lebih baik baik daripada dengan menggunakan pendekatan kooperatif tipe Think Pair Share.

\section{PERSANTUNAN}

Ucapan terima kasih diucapkan kepada pihak-pihak yang telah membantu dalam melaksanakan penelitian ini. Ucapan terima kasih diucapkan kepada: (1) Tim Editorial dan Mitra Bebestari Jurnal Bahastra yang telah bersedia menerbitkan artikel ini; (2) kepala SMP Negeri 12 Padang; (3) guru Bahasa Indonesia kelas VII di SMP Negeri 12 Padang; dan (4) siswa/i kelas VII SMP negeri 12 Padang yang telah bersedia menjadi sampel dalam penelitian ini.

\section{DAFTAR PUSTAKA}

Arianto, Riki Devid dan Lusia Rakhmawati. 2013. "Perbandingan Model Pembelajaran Kooperatif Tipe Numbered Heads Together (NHT) dengan Tipe Think Pair Share (TPS) terhadap Hasil Belajar Siswa pada Standar Kompetensi Menerapkan Dasar-Dasar Teknik Digital di SMK Negeri 2 Lamongan". Jurnal Pendidikan Teknik Elektro, Vol. 02 No. 1, hal. 319-326.

Hartati, Sari dan Suciati Sudarisman. 2011. "Perbedaan Pengaruh Pembelajaran Kooperatif Tipe Think Pair Share dan Numbered Head Together 
terhadap Prestasi Belajar Biologi Peserta Didik Kelas 8 Semester 1 Di SMP Negeri 12 Kota Magelang". Prosiding Seminar Nasional VIII Pendidikan Biologi. Semarang: Universitas Negeri Semarang.

Huda, Nurul. 2015. 'Penerapan Model Pembelajaran Kooperatif Tipe Numbered Head Together dalam Meningkatkan Aktivitas Belajar Siswa Kelas VIII-2 SMP Negeri 4 Medan”. School Education Journal PGSD FIP Unimed, Vol. 4, No. 1, hal 141-150.

Ibrahim, dkk. 2005. Pembelajaran Kooperatif. Surabaya: UNESAUniversity Press.

Kemendikbud. 2013. (buku siswa). Bahasa Indonesia Wahana Pendidikan untuk SMP. MTS Kelas VII. Jakarta: Kementrian Kependididkan dan Kebudayaan.

Kosasih, E. 2016. Jenis-Jenis Teks. Bandung: Yrama Widya.

Lie, Anita. 2005. Cooperatif Learning: Mempraktikkan Cooperatif Learning di Ruang-Ruang Kelas. Jakarta : Grasindo.

Mahsun. 2014. Teks Dalam Pembelajaran Bahasa Indonesia. Jakarta: Rajawali Pers.

Naf'anudiniyah, dkk. 2013. "Efektivitas Pembelajaran Kooperatif dengan Pendekatan Jelajah Alam Sekitar (JAS) pada Kelas VIII di SMP Negeri 1 Kediri Lombok Barat". Jurnal Kependidikan, Vol. 12, No. 2, hal. 171-177.

Rusman. 2012. Model-model Pembelajaran: Mengembangkan Profesionalisme Guru. Jakarta: PT Raja Grafindo Persada.

Sianturi, Devima dan Syahnan Daulay. 2015. "Pengaruh Model Pembelajaran Kooperatif Tipe Think Pair Share terhadap Kemampuan Menulis Teks Deskripsi oleh Siswa Kelas VII MTs As-Syarif Kuala Beringin
Tahun Pembelajaran 2014/2015". Kode: Jurnal Bahasa, Vol. 4, No. 1, hal. 1-13.

Trianto. 2012. Mendesain Model Pembelajaran Inovatif-Progresif. Jakarta: Kencana Prenada Media Group. 